\title{
Blended Learning Model Development in Conflict Management and Resolution Course
}

\author{
Anita Afriani Sinulingga ${ }^{1, *}$ Putiviola Elian Nasir ${ }^{2}$ \\ 1, 2 International Relations Department, Faculty of Social and Political Sciences, Andalas University, Limau Manis, \\ Padang, West Sumatra 25163, Indonesia \\ ${ }^{*}$ Corresponding author. Email: anitaafriani@soc.unand.ac.id
}

\begin{abstract}
The purpose of this study is to describe the application of the blended learning model in the Conflict Management and Resolution course. Through the application of this method, it is hoped that the findings will be in the form of an analysis of the effectiveness of blended learning. The focus of learning effectiveness assessment is not on learning outcomes, but on a process that includes level of student participation and learning motivation. The research was carried out in four stages, namely defining, designing, developing and distributing. The development of this learning model was carried out for the 3rd semester students of 2019, totaling 56 people. Through online learning questionnaires, it can be explained that the blended learning method is able to provide space for students to be actively involved and have high motivation in learning activities. This illustrates that the learning method can be effectively implemented in learning activities. It can be concluded that the effectiveness of learning in Management and Conflict Resolution course using the blended learning model is quite, considering the process aspect.
\end{abstract}

Keywords: blended learning, participation level, learning motivation, Conflict Management and Resolution

\section{INTRODUCTION}

Until recently, human civilization has tended to be characterized by peace and war. The conditions of war itself, especially in the era of World War I in 1919, were the forerunner of the birth of International Relations study in England. The study of International Relations itself claims that the main agenda for learning is to create world peace. In this lesson, various aspects of intrastate conflict and mechanisms that can be applied to resolve these conflicts are discussed intensively. In International Relations Department, Andalas University itself, conflict and peace studies are formalized in the Conflict Management and Resolution course. This course is expected to strengthen students' understanding of conflict and will be able to develop critical thinking related to how actors handle these conflicts in nonviolent ways.

In general, the course applies the SCL (Student Centered Learning) learning method by combining lecture methods, small group discussions, assignments and presentations. For this course, the learning material is delivered by providing lecture handouts equipped with teaching materials in the form of powerpoints. All lecture materials, assignments and assignment assessments are collected through the Ilearn or the online learning system of Andalas University through fisip.ilearn.unand.ac.id. This determination is also felt to be known by students so that students have better preparation in the learning process in class. Learning outcomes evaluation is adjusted to the learning method and is classified into formative and summative evaluation. Formative assessment is through individual assignments and group assignments with $30 \%$ score weight each. Meanwhile, summative evaluation is through semester exam at the middle and end of the semester with $20 \%$ score weight each. Previously, the RPS was delivered and discussed with students at the beginning of the lecture.

However, despite having applied the SCL method in course learning process, there are still several problems in the learning process of this course. First, some students tend to be passive, although some are very active and responsive in lectures. For these students, the lecturers had difficulty ensuring their understanding of the lecture material, especially because of the analytical and practical aspect of this course. Second, the desire to seek new knowledge and 
insights is still low. Students only depend on the lecture material provided by the lecturer in the class. Students tend to be lazy to read which is evaluated from the sources cited in lecture assignments (limited online sources). Third, the results of student learning evaluations are not satisfactory. Although $84 \%$ of students pass this course, only about $17 \%$ of students received the maximum grade of $\mathrm{A}$. Most students received $\mathrm{B}+$ and $16 \%$ of students failed this course. Based on these problems, it is necessary to seek efforts to improve the quality of learning through the blended learning model.

\section{BLENDED LEARNING MODEL}

As an impact of civilization development, globalization has resulted to many changes, especially in the development of information technology (IT) which is able to disguise boundaries of distance and time. IT development also has significant influence in the education world, especially regarding access to class material and also the learning process. Blended learning is a learning technique that was born from advances in IT and has proven effective in increasing student interest in learning (Albrecht, 2006 in (2), and also maximizing learning output (Bourne and Seaman, 2005 in (2).

In simple terms, blended learning is a combination of two learning process techniques, which are the traditional face-to-face version of the classroom, and the use of information technology (the internet). Both are used for the process of interaction and the provision of materials and collection of assignments. But in reality, blended learning is a challenge in itself, especially because this type of learning redesigns or restructure traditional teaching concepts which have been understood as the most appropriate technique, and incorporate new approaches (2) which, although friendly to students, can be a limitation for the teacher. interrelated factors; from the student side, it is not only about understanding what is being learned, but also "... is associated with..., how they approach their learning, and how they perceive their learning context", and from the teacher's side, which is understanding the concept of teaching and how learning takes place, "... how teachers perceive student learning, how they conceive of teaching, and how they approach the learning and teaching experience" (3). This indicates that the approach to learning, or what is known as the learning process, has a significant role in ensuring the quality of output.

According to Branch (1999) in (1), traditional learning has eight subsystems which are students, content, media, teachers, fellow students, duration, purpose and context. If this learning system is adapted to a blended learning system, it basically still has the same subsystem but with additional elements. In this regard, Wang, Han and Yang (1) created a system known as the Complex Adaptive Blended Learning System (CABLS) which describes six subsystems of blended learning types. The CABLS scheme is explained in Figure 1.

Figure 1 describes that the subsystem in blended learning is not much different from the traditional learning subsystem. However, there is an additional subsystem in the CABLS which actually exists in the traditional subsystem but is not explored by Branch. According to Wang, Han and Yang (1), the system that has "changed" and became significant in blended learning are technology, support for learning and institutions. The distinctive aspect of blended learning is the existence of asynchronous and synchronous online learning experiences (technology), the availability of technical assistance regarding the use of the internet and online learning media (learning support), and the role of strong institutions (institutions). All of these subsystems have their respective elements, and are dependent and

Learning quality are evaluated by two main

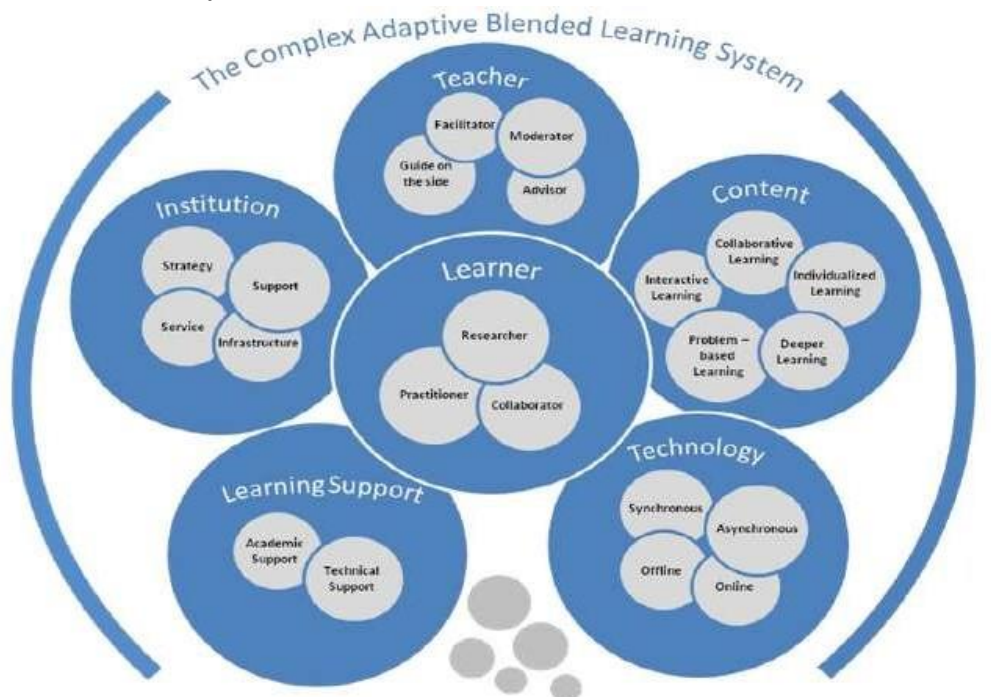

Figure 1. Subsystem of Complex Adaptive Blended Learning System (CABLS) Sumber: Wang, Han dan Yang (1) 
influence each other. This model made by Wang, Han and Yang (1) is a general model that has actually been used by various institutions, although not maximally. The shift in the important role of institutions and technology support in this model is also supported by the research of Ellis and Calvo (3), which states that these two factors significantly influence the success of blended learning.

As stated by Branch (1999) (2) and Wang, Han and Yang (2), students are one of the elements in blended learning. This is supported by Tselios, Daskalakis and Papadopoulou (4) who state that the success of blended learning depends on students' perceptions of this system, which then affects their attitudes in learning. There is a positive perception that students associate with blended learning learning process, thus providing positive output as well. This is supported by Young (2008) in (5) who agrees that blended learning, for example asynchronous discussion, is able to increase the achievement of learning outcomes.

Furthermore, Delialioglu and Yildirim (6) argue that the success of blended learning lies not in technology alone, but in the design of the system itself. In their research, Delialioglu and Yildirim (6) discovered that students were more satisfied with blended learning due to several factors. The first factor is the clarity of the blended learning class goals; students feel the goals of this type of class are sharper and more focused. Another advantage of blended learning is students' satisfaction with variations in the learning process. Students are also highly satisfied by the content in online learning, as well as access to various knowledge through an easy way. Blended learning also provides freedom for students to choose to do certain activities in class, face-to-face, such as applying what they learn through online media content.

From these various studies it can be concluded that there is a general agreement that blended learning is a learning system that enables students to achieve learning outcomes, which that in the end it affects student output. Factors that should be explored more are the learning design and student elements of this alternative learning system.

At Andalas University, the electronic-based learning process is known as the Interactive Learning application or abbreviated as iLearn. The iLearn concept which is implemented at Andalas University also adopts the concept of blended learning. iLearn is a learning medium that utilizes technology using computer network media to facilitate the learning process. In addition to learning through face-to-face meetings, this system allows interaction between lecturers and students in the form of online learning with various assignments and learning materials. Through iLearn, students can access assignments and

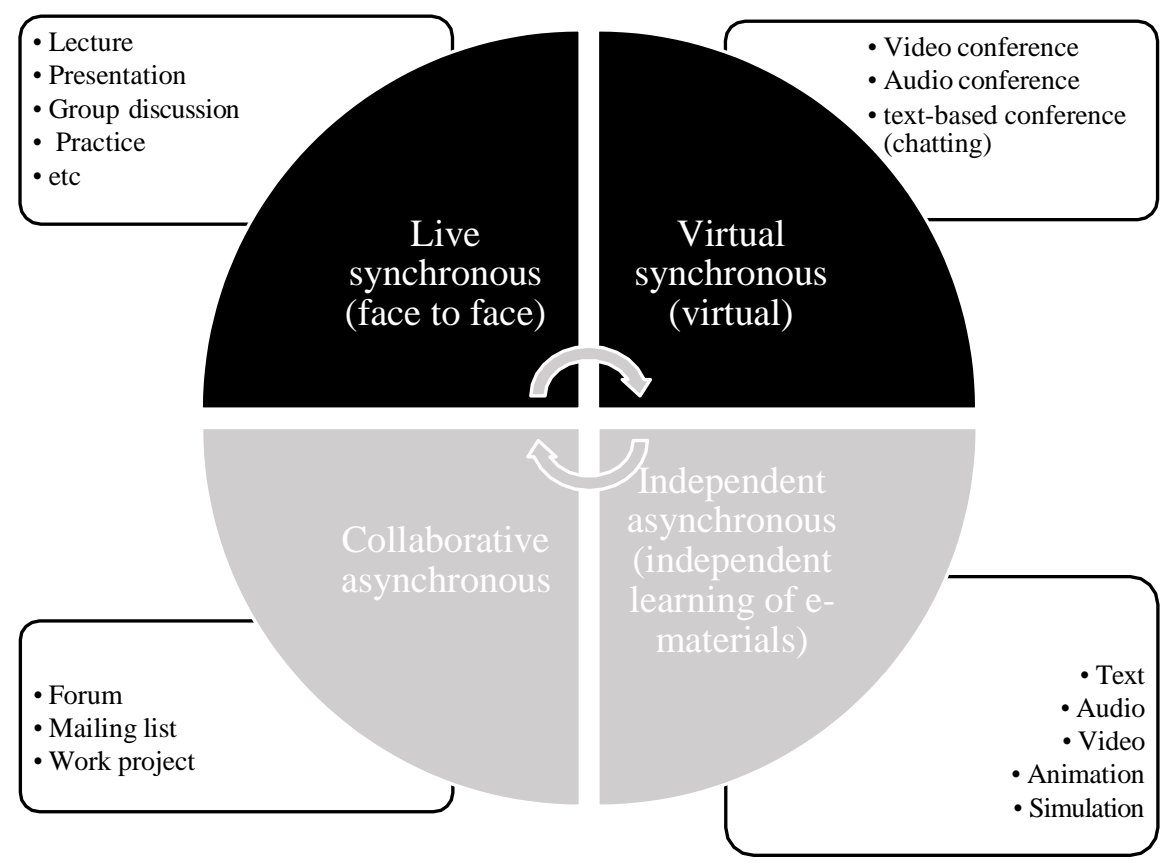

Figure 2. Blended Learning Characteristic and Setting Source: modified from Chaeruman \& Maudiarti 
assessment related to these assignments. This rapid system allows lecturers to make improvements during the learning process without having to wait for the process to end first. In addition to providing learning materials online, this application also helps with paperless assignments. This reduces students' expenses that students will otherwise have to allocate for assignments. This application is also useful in training students' discipline in doing lecture assignments because students are required to submit their assignments within the due date for submitting assignments.

\section{RESULT AND DISCUSSION}

\subsection{Blended Learning Learning Model Implementation in Conflict Management and Resolution Course}

Blended learning means learning patterns that contain elements of mixing or combining one pattern with another. This learning model combines synchronous and asynchronous learning settings in order to achieve learning objectives. Synchronous learning is learning activities that are conducted at the same time and in the same or different places, while asynchronous learning is learning activities conducted at different times and places (8). The characteristics of blended learning are described in Figure 2 (7).

Allen et al (9) explained the proportion of content delivered online and divided it into clear categories such as blended learning, traditional learning, web facilitated learning, and online learning. A learning can be said to use a blended learning model if the portion of e-learning usage is in the $30-79 \%$ range combined with face to face learning. It can be concluded that a learning model is blended learning model if online learning accounts for under $80 \%$ of the total learning activities (10). However, due to the spread of Covid- 19 Virus pandemic in Indonesia, West Sumatra and Padang in particular, the Conflict Management and Resolution course has generally been delivered through online learning in an asynchronous form, both independent and collaborative and utilizes through Andalas University LMS at the address http://fisip.ilearn.unand.ac.id/course/view.php?id=2 095 (for class A) and http://fisip.ilearn.unand.ac.id/ course / view.php? id = 2096 (for class B). Borrowing the thoughts of Thiagarajan et al (11), the research and development method developed a 4D (Four D) learning device development model. This research was designed with four stages of development, namely the stage of define, design, development and dissemination. In more detail, the implementation stages of the 4D research are described in Table 1.

In general, the learning process applies the SCL principles through several variations, including Small Group Discussion, Discovery Learning and Project based Learning (12). Learning takes place using the
iLearn. As previously explained, learning is generally conducted synchronously. Asynchronous learning is applied because it can be done in different dimensions of space and time (anytime and anywhere). The point that differentiates independent and collaborative asynchronous is the number of participants and the media used. Independent asynchronous learning media used in print and digital forms can be in the form of books, journals, modules, or through the Youtube channel in the form of doc, ppt, pdf, mp4, and so on. Meanwhile, collaborative learning that involves more than one person includes class projects, Whatsapp, email or discussion forums.

Learning effectiveness can be assessed based on student learning outcomes and process aspects such as active participation and student learning motivation (13 p. 34). Learning outcomes assessment is evaluated through summative and formative assessments while the learning process assessment is evaluated through student response questionnaires. Summative assessment is conducted through tests, such as semester exams, while formative assessments place more emphasis on the learning process through independent or group assignments. Meanwhile, questionnaires were distributed to students to determine student responses to online learning in the Conflict Management and Resolution course. This study further describes the effectiveness of learning based on process aspects that emphasize the dynamic interaction of students as learning subjects who are able to develop their potential through independent learning and the goals that have been set are achieved effectively.

The aspects in the learning process include active participation and student motivation. Activeness has an important role in achieving learning goals. The implication of the principle of student participation according to Dimyati and Mudjiono (14 p. 51) is in the form of behaviors such as searching for information needed, analyzing experimental results, being curious, has creation, and so on. Student participation further demands direct student involvement in the learning process. Meanwhile, student participation during the learning process is an indicator of the desire or motivation of students to learn. Students are said to be participatory when there are specific behavioral characteristics, such as frequently asking lecturers or other students, doing assignments given by the lecturer, being able to answer questions, being happy to be given lecture assignments, and so on. Dimyati and Mudjiono (14 p. 43) further argued that motivation becomes a goal and a tool in learning. Motivation is the energy that drives and directs student participation in learning and has an influence on the success rate of learning. Student motivation in learning is reflected in several indications, such as the desire to succeed, encouragement and learning necessities, hopes and aspirations for the future, rewards in learning, interesting activities in learning, and a conducive learning environment. 
Table 1. 4D Research Implementation Stages

\begin{tabular}{|c|c|}
\hline Stages & Implementation \\
\hline Define & $\begin{array}{l}\text { 1. Lecturer conducts self-evaluation of the previous learning process, } \\
\text { 2. Lecturer analyzes students' general characteristics of students } \\
\text { 3. Lecturer determines general learning objectives. }\end{array}$ \\
\hline Design & $\begin{array}{l}\text { 1. Lecturers prepare a blended learning based RPS which inludes learning outcomes and } \\
\text { course learning outcomes. } \\
\text { 2. Lecturers design learning methods and activities. Learning is conducted online } \\
\text { containing activities in the form lectures, then the lecturer arranges lecture } \\
\text { assignments in the form of responding to a case, quiz or resume and students } \\
\text { responding / doing the assignment. } \\
\text { 3. Lecturers identify and select instructional technology media. Most of the lectures use } \\
\text { the Independent Asynchronous or Collaborative Asynchronous method. The choice } \\
\text { of this method is considered more effective and more economical for lecturers and } \\
\text { students. } \\
\text { 4. Lecturers design learning assessment method and compiles the assessment rubric. This } \\
\text { course gives a greater weight to the assessment of lecture assignments: } 30 \% \text { each for } \\
\text { independent and group assignments, while } 20 \% \text { each for midterm and final semester } \\
\text { exams. } \\
\text { 5. Students provide input and suggestions for the RPS prepared by the lecturer. }\end{array}$ \\
\hline Develop & $\begin{array}{l}\text { 1. Lecturers compile instructional technology media in the form of instructional videos } \\
\text { and Ms. documents Office. } \\
\text { 2. This lecture uses the Ilearn system of Andalas University. } \\
\text { 3. Through Ilearn, lecturers arrange lecture settings. Videos compiled by lecturers will } \\
\text { be uploaded to Ilearn. Then the lecturer arranges the 'Chat' menu settings, the 'Forum' } \\
\text { menu, the 'Assignment' menu, and the 'Quiz' menu for each week according to the } \\
\text { lecture schedule previously determined by the institution. }\end{array}$ \\
\hline Disseminate & $\begin{array}{l}\text { 1. Students access Ilearn according to lecture schedule then listen to lecturers' } \\
\text { presentations via the learning video link. } \\
\text { 2. Students mark their attendance through Ilearn. } \\
\text { 3. Students work on lecture assignments that have been instructed by the lecturer in the } \\
\text { Ilearn dropbox. } \\
\text { 4. Lecturers provide assessment and feedback on student assignments. } \\
\text { 5. At the end of the semester, lecturers and students evaluate the lessons for one semester } \\
\text { as lessons learned in preparing the RPS for the following semester. }\end{array}$ \\
\hline
\end{tabular}

Source: modified from Tiagarajan et al. (11)

\subsection{Student Participation and Motivation through Blended Learning Model in Conflict Management and Resolution Course}

This research uses a closed questionnaire with a Likert scale, where students as respondents answer statements in accordance with the five predetermined answer choices, including strongly agree, agree, disagree, disagree, and strongly disagree, by putting a checklist on the questionnaire given. The questionnaire was distributed online to 56 participants in the Conflict Management and Resolution class who were 3rd semester students majoring in International Relations, Andalas University. The assessment consists of 20 questions, each part is given 10 statements to assess the level of participation and learning motivation of students. Of the 20 statements conveyed in the questionnaire, the assessment of "Agree" is the highest response given by students (10 times), the next is the assessment of "Strongly Agree" (7 times) and the last is the assessment of "Disagree" (3 times). In more detail, the results of the analysis of student participation level of and learning motivation are described in Table 2.

In the level of participation variable in the blended learning learning response questionnaire, $60 \%$ chose "Agree". This data describes that students often complete tasks observed from the level of frequency and involvement of students in conducting physical learning activities. Another explanation is that students are often active in developing skills, solving problems, finding solutions, comparing concepts, conducting research, and concluding research results regarded from the level of student involvement in online learning activities. Meanwhile, in the learning motivation variable, students' assessment for the statements in the blended learning learning response questionnaire were $60 \%$ for "Strongly Agree". This indicates that students have a strong desire to succeed in the Conflict Management and Resolution course seen from the enthusiasm of students in participating in learning. Students also have strong motivation and feel the need for learning evaluated from their motivation for the fulfillment of self-competence. 
Table 2. Questionnaire Analysis Results on Student Participation Level and Learning Motivation

\begin{tabular}{|c|c|c|c|c|}
\hline No. & Indicator & Evaluation & Percentage & Statement \\
\hline \multicolumn{5}{|c|}{$\begin{array}{l}\text { Student Participation } \\
\end{array}$} \\
\hline 1 & Asking questions & $\mathrm{KS}$ & 32 & $\begin{array}{l}\text { Students rarely ask when having learning } \\
\text { difficulties }\end{array}$ \\
\hline 2 & $\begin{array}{l}\text { Completing } \\
\text { assignments }\end{array}$ & $\mathrm{S}$ & 38 & Students are sometimes eager to do assignments \\
\hline 3 & Responding to questions & $\mathrm{KS}$ & 41 & $\begin{array}{l}\text { Students seldom respond to questions from } \\
\text { lecturers and other students during learning }\end{array}$ \\
\hline 4 & Answering questions & $\mathrm{KS}$ & 46 & $\begin{array}{l}\text { Students seldom respond } \\
\text { questions from lecturers and other students } \\
\text { during learning }\end{array}$ \\
\hline 5 & Skill practive & $\mathrm{S}$ & 43 & $\begin{array}{l}\text { Students often practice and develop abilities and } \\
\text { skills both theoretically and practically }\end{array}$ \\
\hline 6 & Problem solving & $\mathrm{S}$ & 35 & $\begin{array}{l}\text { Students often try to find problem solutions by } \\
\text { linking concepts and practices }\end{array}$ \\
\hline 7 & Problem solving & $\mathrm{S}$ & 41 & $\begin{array}{l}\text { Students often seek information to find } \\
\text { solutions in competency development }\end{array}$ \\
\hline 8 & Comparing concept & $\mathrm{S}$ & 49 & $\begin{array}{l}\text { Students often look for strengths and } \\
\text { weaknesses in the concept of learning materials }\end{array}$ \\
\hline 9 & $\begin{array}{l}\text { Concluding learning } \\
\text { outcomes }\end{array}$ & SS & 49 & $\begin{array}{l}\text { Students always conduct research mastered } \\
\text { concepts }\end{array}$ \\
\hline 10 & $\begin{array}{l}\text { Concluding learning } \\
\text { outcomes }\end{array}$ & $\mathrm{S}$ & 46 & $\begin{array}{l}\text { Students often draw conclusions and results } \\
\text { from the research that have been conducted }\end{array}$ \\
\hline \multicolumn{5}{|c|}{ Student Learning Motivation } \\
\hline 11 & Desire to succeed & $\mathrm{S}$ & 35 & $\begin{array}{l}\text { Students often try to master theoretical and } \\
\text { practice abilities in learning }\end{array}$ \\
\hline 12 & Desire to succeed & SS & 49 & $\begin{array}{l}\text { Students always try to master learning process } \\
\text { and materials }\end{array}$ \\
\hline 13 & $\begin{array}{l}\text { Drive and learning } \\
\text { necessities }\end{array}$ & SS & 38 & Students are always passionate about learning \\
\hline 14 & $\begin{array}{l}\text { Drive and learning } \\
\text { necessities }\end{array}$ & SS & 35 & $\begin{array}{l}\text { For students, Conflict Management and } \\
\text { Resolution class is a significant requirement in } \\
\text { fulfilling self-competence }\end{array}$ \\
\hline 15 & Hope and future goals & SS & 46 & $\begin{array}{l}\text { Students are always motivated to make the } \\
\text { Conflict Management and Resolution class } \\
\text { succeed }\end{array}$ \\
\hline 16 & Hope and future goals & $\mathrm{S}$ & 38 & $\begin{array}{l}\text { Students are often motivated to learn to achieve } \\
\text { their goals }\end{array}$ \\
\hline 17 & Learning achievement & $\mathrm{S}$ & 38 & $\begin{array}{l}\text { Students often have useful and highly motivated } \\
\text { learning experiences }\end{array}$ \\
\hline 18 & Learning achievement & SS & 35 & $\begin{array}{l}\text { Students always try to be the best in learning } \\
\text { activities }\end{array}$ \\
\hline 19 & $\begin{array}{l}\text { Interesting activities in } \\
\text { learning }\end{array}$ & $\mathrm{S}$ & 30 & $\begin{array}{l}\text { For students, Conflict Management and } \\
\text { Resolution class is often motivating, fun, and } \\
\text { support the development of self-competence }\end{array}$ \\
\hline 20 & $\begin{array}{l}\text { Conducive learning } \\
\text { environment }\end{array}$ & SS & 32 & $\begin{array}{l}\text { Students always feel comfortable, calm, and } \\
\text { impressed in learning activities }\end{array}$ \\
\hline
\end{tabular}

Furthermore, students have high hopes, aspirations, learning experiences, and achievements in learning through Conflict Management and Resolution class with the blended learning model. This can be seen from strong student motivation to explore and develop their competence in learning. Finally, students have high motivation whis is indicated by conducive learning environment in the blended learning Conflict Management and Resolution course.

Based on the results and explanations above, it can be concluded that the learning process in the blended learning model of Conflict Management and Resolution course was able to provide space for students to be actively involved and have high motivation in learning activities. This provides an overview of the effective implementation of the blended learning model learning application in the Conflict Management and Resolution courses.

\section{CONCLUSION}

The learning effectiveness assessment are evaluated from from the result aspect and the process aspect. This study focuses on the assessment process which includes two variables, namely the level of participation and student learning motivation. The application of the blended learning model in the Conflict Management and Resolution course is considered quite effective, marked by the assessment given by students in the learning response 
questionnaire; $85 \%$ of the ratings in the questionnaire were in the 'Agree' and 'Strongly Agree' categories, although the 'Agree' rating received a higher response of $50 \%$. Meanwhile, only $15 \%$ received a "Disagree" rating. In detail, regarding the student participation level variable, $60 \%$ received satisfactory assessment, only $30 \%$ received poor responses such as whether students ask questions, respond to questions and answer questions from lecturers and other students. Meanwhile, for the student learning motivation variable, $60 \%$ of students gave outstanding assessments while $30 \%$ gave favorable assessments. In this case, it can be concluded that the effectiveness of learning in Conflict Management and Resolution course using the blended learning model is quite high when viewed from the process aspect.

\section{REFERENCES}

[1] Wang, Yuping, Han, D and Yang, Juan. Revisting the Blended Learning Literature: Using a Complex Adaptive Systems Framework. 2, s.1. : Journal of Education Technology \& Society, 2015, Vol. 18.

[2] Garrison, D Randy and Vaughan, Norman D. Blended learning in higher education: framework, principles, and genuine. San Francisco: JoseyBass, 2008.

[3] Ellis, Robert A and Calvo, Rafael A. Minumum Indicators to Assure Quality of LSM-supported Blended Learning. 2, s.1.: Journal of Educational Technology \& Society, 2007, Vol. 10.

[4] Tselios, Nikolaos, Daskalakis, Stelios and Papadopoulou, Maria. Assesing the Acceptance of a Blended Learning University Course. 2, 2011, Journal of Educational Technology \& Society, Vol. 14. ISSN 1176-3647.

[5] Zhu, Chang. Student satisfaction, performance, and knowledge construction in online collaborative learning. 1, 2012, Journal of Educational Technology \& Society, Vol. 15, pp. 127-136.

[6] Delialioglu, Omer and Yildirim, Z. Students' Perceptions on Effective Dimensions of Interactive Learning in a Blended Learning Environment. 2, 2007, Journal of Educational Technology \& Society, Vol. 10, pp. 133-146.

[7] Chaeruman, Uwes Anis and Maudiarti, Santi. Quadrant of Blended Learning: a Proposed Conceptual Model for Designing Effective Blended Learning. 1, Jakarta: s.n., 2018, Jurnal Pembelajaran Inovatif, Vol. 1, pp. 1-5.

[8] Chaeruman, Uwes A. [Online] 2011. [Cited: September 27, 2020.] http://www.teknologipendidikan.net/2011/06/21/ implementing-blended- learning-a-case-basedsharingexperience.

[9] Allen, Isabel Elaine, Seaman, Jeff and Garrett, Richard. Blending in: The Extent and Promise of Blended Education in the United States. United States: the Sloan Consortium, 2007.

[10]Allen, Elaine I and Seaman, Jeff. Class Differencess: Online Education in the United States, 2010. United States: Sloan Consotium, 2010. p. 5.

[11]Thiagarajan, Sivasailam, Semmel, Dorothy S and Semmel, Melvyn I. Instructional Development for Training Teachers of Exceptional Children: a Sourcebook. United States: Indiana University, 1974.

[12]LP3M. Panduan Praktis Pelaksanaan StudentCentered Learning (SCL): Meningkatkan Interaksi Mahasiswa dan Dosen dalam Pembelajaran. Padang: Universitas Andalas, 2014.

[13]Sudjana, Nana. Dasar-dasar Proses Belajar Mengajar. Bandung: Sinar Baru Algensindo, 2009.

[14]Dimyati and Mudjiono. Belajar dan Pembelajaran. Jakarta: Rineka Cipta, 2009. 